Article

\title{
An Integrated Organisational Culture for Sustainable Environmental Performance in the Nigerian Context
}

\author{
Olufunke P. Adebayo *(D), Rowland E. Worlu, Chinonye L. Moses and Olaleke O. Ogunnaike \\ Department of Business Management, College of Management \& Social Sciences, Covenant University, \\ Ota 112212, Nigeria; rowland.worlu@covenantuniversity.edu.ng (R.E.W.); \\ chinonye.moses@covenantuniversity.edu.ng (C.L.M.); olaleke.ogunnaike@covenantuniversity.edu.ng (O.O.O.) \\ * Correspondence: olufunke.adebayo@stu.cu.edu.ng
}

Received: 10 August 2020; Accepted: 7 September 2020; Published: 10 October 2020

\begin{abstract}
To remain competitive within the present inherent business environment, there is a demand for organisations to embrace an integrated culture-behaviour for performance that enables them to adopt a critical engine for a more sustainable working environment. Organisational culture, which is a reflection of predominant valued beliefs, is expected to influence a sustainable environmental performance. Evidence abounds of several organisational activities with adverse impacts on humans and the environment. The study examines an organisation's processes that can be incorporated as a culture to ensure a more sustainable working environment. This paper proposes the use of six organisational culture practices (core value, reporting system, task performance, clarity of roles, careful deliberations, and distinctive identity) to find out organisation values, as well as individual preferences in enhancing an immediate sustainable environment. The study selected 480 employees of Fast-Moving Consumer Goods (FMCGs) firms who are active in their organisational work processes; 358 responded, and as such, was deemed as a valid research sample. The empirical analysis was carried out using a variance-based Structural Equation Modelling with partial least squares for the path-modelling (PLS-SEM), both for the Algorithm Model, and the Bootstrapping Model with $\beta$ and $p$-values obtained from the findings. The findings provide empirical evidence that there is a significant level of influence of organisational culture on environmental performance. However, among the organisational practices, task performance has the least influence on environmental performance. This implies that organisations should invest more in the dimensions of organisational culture with higher performance-importance, while adequate attention should be given to variables with the least influence on the target construct of environmental performance.
\end{abstract}

Keywords: environmental performance; FMCGs; organisational culture; sustainable environment; southwest Nigeria

\section{Introduction}

The inherent dynamism of the business environment has made it imperative for organisations to imbibe in a more ethical culture that will not only accomplish, but also sustain a functional sustainable immediate environment. In advancing performance and competitiveness, organisations tend to build up more capacity in production processes, however, these activities are engaged in a planned culture geared towards sustaining a more friendly environment. In promoting a distinctive culture, organisations are expected to sense a display responsibility within the host communities, where the business activity is operated [1]. Culture is seen as a life-wire of every organisation which sharpens their organisational practice; also, decisions are intertwined around culture internally to determine the outcome to its external environment [2]. Furthermore, Srisathan, Ketkaew, \& Naruetharadhol [3] affirms organisational culture as having a significant impact that strikes a chord in determining organisational performance. 
Therefore, culture as a system integrates values, as well as influences the attitude of the people and their conduct within the organisation [4].

At the advent of globalisation, most organisations have become more industrialised; as such, business practices took a new turn to influence changes in the external business environment, and this is characterised by constant activities that open the environment to fluxes [5]. In a bid to practice in a more ethical manner, the government, through various agencies, had to implement policies and enforce laws to guide work processes in organisations in order to address the management of both humans and the environment [6]. In addition, Felipe, Roldán, \& Leal-Rodríguez [7] and Linnenluecke [8] stated that organisational culture gives the employees the means to properly understand and manage the happenings within their environment, as this enhances the maximization of resources in the host community. However, there are arguments that organisations have to embrace a sustainability-oriented organisational culture to optimize environmental performance $[9,10]$. This is because the proper management of the environment has increasingly become an essential part of the organisation. To this end, organisations stands to benefit from wider publicity and sales when they embrace policies that are pro-environmental [11]. By this, it is required of organisations to undergo a deliberate developmental process in confronting the persistent pattern of behaviour that hinders the organisation from performing higher [12].

The tremendous and far-reaching changes occurring in today's business environment can be attributed to defining and examining the components of its external environment [13]. Organisations cannot operate in isolation of their external environment because every element existing outside the boundary of the organisation has the potential of affecting the organisation. Just as the environment is beneficial to the organisation, organisations, in turn, are increasingly being held responsible for the environment's actions. This is reflected by the growing number of laws, regulations, and penalties to protect and conserve the environment [10]. It is with this operation that demands the measure-up, control, and disclosure of their environmental performance for sustainability [14]. According to Babalola [15], environmental sustainability measures how successful an organisation is able to minimise its negative impacts on the environment, and in turn, increase its positive impact through its activities.

Studies from Iljins, Skvarciany, \& Gaile-Sarkane [16]; Odor [17] and Onyango [18] posit that organisational culture is fundamental to an organisation that drives for development and sustainability by doing things differentially, which consequently sharpens the employees' beliefs, and actions. Culture is clearly an important ingredient of effective institutional performance for sustainability. However, several management processes have adverse impact on the environment ranging from pollution, poor waste management and production of non-biodegradable products [9,19-21]; studies sought for the ethical value of an organisational culture's impact on the environment, but fail to address the issues of environmental performance. However, the study of Magsi, Ong, Ho, \& Hassan [2] was among large proportions of studies conducted in developed countries, but outside the Nigerian cultural context, and this cultural difference may not be directly applicable to the Nigerian context.

In the light of the area of concerns identified, this research work will be directed towards the highlights of the general and specific objectives of this study.

\subsection{Organisational Culture}

An organisation is a reflection of its beliefs and is predominantly valued through its culture, which serves as a window through which the world could see through [22]. As it is simply used, culture is the lifestyle of the people. Therefore, culture appears in all aspect of human lifestyle, and this constitutes from the highest level of the management, to the lowest of the employees in the organisation. Additionally, organisational culture can be defined as a system of a shared value of assumptions, norms, traditions, convictions, policies, and beliefs which are recognised and commonly accepted as a way of life, and interpreted by the members of the organisation, to constitute the way work processes are to be carried out within the organisation [23,24]. According to Ibidunni, \& Agboola [25], as people 
are employed, and through interactions with clients, cultural values are imported into the organisation, which sometimes may have contradictory quality with that of the organisational values.

Moreover, several authorities in management [26-29] had taken special interest in the study of organisational culture, making an effort to classify culture, based on different perceptions in understanding the subject and its complexity. Culture can be understood in terms of different dimensions, and this depends on what is most emphasized within the organisation. Though, it is impossible for an organisation to possess all dimensions of culture, but multiples of some cultures may co-exist in a single organisation in the form of subcultures and countercultures [30].

\subsection{Environmental Performance}

The tremendous and far-reaching changes occurring in today's business environment are understood by defining and examining components of the external environment [31]. An organisation cannot operate in isolation of its external environment; all elements existing outside the organisation's boundary affects it. Just as the environment is beneficial to the organisation, the environment also is expected to benefit from organisational actions [32]. This is reflected by several laws, regulations, and penalties enacted to protect and conserve the environment. There is also a demand on organisations to measure-up, control, and disclose their environmental performance [14,33]. According to Babalola [15], environmental performance measures how successful an organisation can minimise its negative impacts on the environment, and in turn, increases its positive effects.

From the same perspective as abovementioned, Latan, Jabbour, Jabbour, Wamba, \& Shahbaz [34] defines environmental performance as a set of initiatives which the organisation takes to reduce the impact of their operations on the natural environment. This can be through products, processes, and corporate policies such as reducing energy consumption and waste, sustainable green resources, and environmental management system implementation. Moreover, business activities have posed a significant threat to the environment through its work processes, emission of poisonous gas, production of non-biodegradable packaging materials, poor waste management, and other industrial pollution [35]. However, in today's global environmental demands, Chin, Tat, \& Sulaiman [35] noted that attention had been focused away from a firm's performance primarily on the creation of wealth through superior economic performance, to focus on environmental and social performance, while achieving high financial performance.

\section{Empirical Reviews of Literature}

Baird, Su, \& Tung [9] examines the association between the four organisational culture dimensions, namely teamwork, innovation, outcome orientation and attention to detail, and the adoption of environmental activity management (EAM). The findings indicate that three of the dimensions exhibit an association with specific dimensions of EAM. Magsi et al. [2] considers it necessary to conduct an examination on the impact of organisational culture on environmental performance with the emphasis on organisations to implement environmental strategies with the support of imbibing organisational culture. The finding was that organisational culture as a latent variable has a strong impact on environmental performance. Pham, Phan, Tučková, Vo, \& Nguyen [36] examines the effect of two green practices on organisational citizenship behaviour toward the environment, and the moderating role of green organisational culture. Akhavan, Sanjaghi, Rezaeenour, \& Ojaghi [37] also look at the dimension of studying the effects of organisational culture on environmental responsiveness capability with the mediation of knowledge management. The result is positive with organisational culture having a significant relationship with environmental responsiveness capability. In examining the impact of culture and environmental pressures on IT project performance, Gu, Hoffman, Cao, \& Schniederjans [38] specifically examines four dimensions of organisational culture (i.e., institutional collectivism, results orientation, positive work environment, leadership risk tolerance) and environmental pressures that are competitive and regulatory in nature. In the findings, the relationship between organisational culture, and IT project performance was moderated by environmental pressures. Consequently, by using 
the moderating role of organisational environment to determine the effect of stability or variability, Aktas, Çiçek, \& Kıyak [39] examined the relationship between organisational culture and organisational efficiency. The result obtained was positive as stability or variability of the internal and external organisational environment and the top manager's values (self-direction and stimulation) plays a moderator role on this relationship. Moreover, several extant literatures promote the organisational greening culture to protect the external environment [40-43]. Furthermore, several other related studies were also conducted in Africa; according to Afum, Agyabeng-Mensah, \& Owusu [44] and Gyasi-Mensah, \& Xuhua [45], it laid claim that the enforcement of the Environmental Assessment and Regulations (EAR) could only be more visible when organisations have to imbibe in green culture as a practice in order to reduce the impact of the organisational practices on the environment. Similarly, Efobi, Belmondo, Orkoh, Atata, Akinyemi, \& Beecroft [46] sought for the increase of adoption of government policies to reduce the high rate of environmental degradations in form of liquid, solid and gas that is prevalent both in Nigeria and Ghana. Additionally, beyond the government rules and regulations to protect the environment, interestingly, Fatoki [47] studies in South Africa asserts that there is an increasing awareness of consumers demanding for more environmentally-friendly products and services for both humans and the sustainability of the environment. Moreover, Fatoki [48] considered the responsibility on the side of organisations in the hospitality industry in South Africa. This is by aligning internal organisational cultural traits for a more sustainable environmental performance, to which the findings ascertained were of significance to the performance of the environment. More so, similar study of Magsi et al. [2] on organisational culture and environmental performance was also conducted in Pakistan; therefore, this cannot be generalised due to different cultural contexts, giving it a gap on the scope of our study. However, the aim of this study is to test it in the Nigerian context.

\subsection{Development of Culture and Sustainable Environmental Performance Hypotheses}

\subsubsection{Core Value and Sustainable Environmental Performance}

It is established that organisational culture are habits that members cultivate over time, for a cause and purpose $[2,49,50]$, while core value is embedded in the organisational culture. Core values are the driving force that propels the organisation towards achieving both the individual and organisational desired goal and change. It is an identity for the organisation to be known and identified by others, which is a uniqueness for the organisation [51]. When an organisation projects and esteems a particular order of value, it is accepted to become as valid by the members of the organisation, who imbibes in it as a lifestyle [49]. This is subsequently passed on to new members to form a culture within the organisation. Employee behaviours can also be sharpened through the accepted and adapted values, which serve as principles for both educational and motivational strategies towards the learning, training and development of the organisation [52]. Therefore, it is an impending danger when an organisation lacks value that are distinct with them, while this can also result into an individual's conflict of interest with that of the organisation [51]. According to Kumar [53], core values are foundational ideologies that serve as guiding principles for every member, who are expected to live by it as a way of influencing the performance of the environment. This study operationalizes organisational culture by adopting core value distinction, which focuses on specific values that depict the nature of the work environment. As a result, the hypothesis is developed:

Hypothesis 1 (H1). Core value positively influences sustainable environmental performance.

\subsubsection{Reporting Structure and Sustainable Environmental Performance}

The culture as practiced within an organisation actually creates the platform for establishing the structure, which is a framework for how the work process is to be implemented. The organisational reporting structure refers to the models of internal relations among the department/unit for easier 
communication and workflow which enables responsibility and decision making to be clarified [54,55]. Organisations are structured to run a clear reporting system, which include organised lines of authority, and a well-designed system that ensures effective coordination of employees across departments [56,57]. A strict compliance to this organised reporting structure gives a higher degree of precision in service for both efficiency and effectiveness. When an organisation practices a good reporting structure as a culture, there is a facilitation for proper arrangement and structuring of work in accomplishing the organisational goals [17]. According to Janićijević [58] and Oshita, Pavao, \& Borges [59], organisations are said to use the reporting structure as their framework of culture for performance. The argument is that for employees to have cognisant knowledge of how best to serve clients or customers, is by having a high degree of precision in service and paying attention to details [60]. Every organisation that values a high level of precision in its reporting system tends to comply with rules and procedures with ease, and does not find this as a difficult task to achieve. Due to the desire for a structured reporting system, and compliance with rules and procedures, cultural value influences the employees in promoting environmental-related responsibilities for sustainability. This assertion gives rise to the hypothesis:

Hypothesis 2 (H2). Reporting structure positively influences sustainable environmental performance.

\subsubsection{Task Performance and Sustainable Environmental Performance}

There is a practice in organisations that defines core job responsibilities and highly promotes result-oriented efforts, that is driven towards the accomplishment of goals. According to Kalia, \& Bhardwaj [61], task performance are technical behaviours, and activities that are required for job performance, which contributes effectively to the performance of organisations. This is often influenced by emphasis on the instrumentality of performance towards organisational goals, that is associated with competency and expertise [62]. The execution of task performance among employees breeds into positive relationships within the organisation. Moreover, task performance can be achieved by meeting up with a company's objectives, or, for instance, when the sales and marketing department have effective sales in their presentations, as this considerably varies between jobs within the same organisation. Daderman, Ingelgard, \& Koopman, [63] and Kappagoda [64] asserts that there is a collaborative effort for all members with a high degree of team work, to translate employees' involvement into action for sustainability. However, Ramos-Villagrasa, Barrada, Fernández-del-Río, \& Koopmans [65] affirms that organisations which practice a high level of task performance are better placed to perform well, and this is sustained as a cultural value. These values thereby lead to an increased environmental sustainability. As a result, the hypothesis is developed:

Hypothesis 3 (H3). Task performance positively influences sustainable environmental performance.

\subsubsection{Role Clarity and Sustainable Environmental Performance}

There is a high-level emphasis on performance when an organisation is not ambiguous in assigning roles. This role means the level of precisions in the task assigned to individuals, and the understanding of other responsibilities in the organisation [66]. This also means that employees are expected to be result-oriented when there is clarity, and as such, they are evaluated based on results, and fulfillment of clearly outlined objectives. Studies have shown that there is an interplay between employees with clear roles, well-informed responsibilities and performance [67]. However, these employees may even tend to unconsciously adopt the culture as their own, as it determines the ethical direction for role clarity [68]. An organisation that is very efficient in its clarity of roles has significantly higher levels of work satisfaction and rates of turnover [69]. As an organisation is mindful of the conduct of analysis of its environmental activities, this analysis is facilitated on clarity. An organisation operates on a cost-cut 
consciousness by a focus on operating in a more efficient way, to improve on processes and enhance overall environmental sustainability for performance. Therefore, this leads to the following hypothesis:

Hypothesis 4 (H4). Role clarity positively influences sustainable environmental performance.

\subsubsection{Deliberation of Issue and Sustainable Environmental Performance}

In organisations, it is a usual approach for executives to deliberate on issues to make numerous decisions, as these decisions are vital to the efficiency, and the effectiveness of work processes within the organisation. Through deliberations, conflicting parties are able to come into a consensus in a way that allows them to make strategic decisions. Decision making plays a fundamental role as a culture for organisations in deliberating issues, as they act as a prime factor either in the success or failure of the organisation $[70,71]$. When an organisation makes strategic decisions, their engagement in deliberation enables new possibilities. This is to reveal action where sole decisions could not earlier be seen. In addition, Gould, Krymkowski, \& Ardoin [72] stated that for people to think positively about the environment—and to make right decisions in regards of the environmental impact-is a function of having deeper understanding of the variables that influences the pro-environmental behaviour. However, these deliberations of issues for decision making, are subjected to the organisational culture; thus, they affect the leadership decision-making process [73].

Hypothesis 5 (H5). Deliberation of issues positively influences sustainable environmental performance.

\subsubsection{Distinctive Identity and Sustainable Environmental Performance}

There is a type of identity that encourages a high degree of uniqueness, adaptivity to change, risk taking, and trying out of new ideas at the workplace. According to Azadehdel, Ooshaksaraie, \& Rajabpour [74] and Taha, Sirkova, \& Ferencova [75], it was affirmed that when an organisation engages these attributes as a culture, it enhances their performance. A distinctive identity influences and maintains the standard for performance and competitive advantage [76]. However, organisations with a distinctive identity have little or no emphasis on status or hierarchy; this is because employees with high performances are celebrated, and the company accommodates failure for better future performance [77]. Moreover, due to the flexibility to changes of this type of organisation, there is a high tendency for the management to opt for better ways of carrying out their processes, and this is at the detriment of environmental management. This serves as an interplay between the standard for performance, and environmental sustainability. Therefore, this argument advances this hypothesis:

Hypothesis 6 (H6). Distinctive identity positively influences sustainable environmental performance.

\section{Materials and Methods}

\subsection{Sample and Data Collection}

The study focus was on a four dominant Fast-Moving Consumer Goods (FMCGs) firms in the industry based on their performances in having large market shares [78], namely Nestle Nigeria Plc., Unilever Nigeria Plc., A.G. Leventis Nigeria Plc. and Dufil Prima Foods Plc., and they are located in southwest Nigeria. This region is home to most industries' headquarters, and as such, serves as the commercial nerve centre of the country [79]. The population of the study consists of 2045 employees. Guilford, \& Fruchter [80] statistical formula was used to calculate, and was adopted to represent the sample size, which is at 480 employees of the firms across various stratification of levels and departments within the firms. Of the 480 copies of the questionnaire that were distributed for data to be collated, a total of 358 copies were retrieved, which accounted for $74.6 \%$ of a response 
rate, and as such, adjudged suitable, and sufficient to carry out the statistical analysis. The 32 items on the questionnaire that made up both the independent (organisational culture), and dependent (environmental performance) variables were selected, and duly tested with related research instruments. Each copy of the questionnaire was structured into two sections. The section (A) with six items was structured to obtain the respondents' demographic data. In the bio-data profile of respondents reported, $76.6 \%$ were men who are in the active age of $31-40$ years forming $52 \%$ of the population. Most of the employees (55.6\%) had a minimum of a first degree as their educational background.

Section (B) featured 12 items under the organisational culture such as "Procedure for performing task in my firm is well explicit to all the stakeholders"; "Symbols and our core values differentiate us from our competitors"; "Our stories convey messages about what is valued in the organisation". Additionally, the environmental performance was also measured with 12 items such as, "I have a positive predisposition towards the production of ecological goods"; "The organisation has sensitised me with its environmental values"; "My organisation produces environmentally-friendly products". All the measured were on a Likert five scale (strongly agree $=5$, agree $=4$, undecided $=3$, disagree $=2$, strongly disagree $=1$ ) to which the participants were confined to answers within the scale. However, participants were allowed to give a more comprehensive view of the subject matter through the open-ended questions. The two open-ended questions were each for the independent and the dependent variable. It was to facilitate respondents' rich levels of knowledge and understanding to further enrich the subject matter in the discussions. Moreover, the samples were collected over the period of July, 2019 and February, 2020 before the lock-down in the month of March, 2020 in Nigeria.

\subsection{Measurement and Analysis}

From the path coefficient table, the T-statistics, $p$-values, Path co-efficient and the $\mathrm{R}^{2}$ were determined. The hypotheses were tested through smart PLS Structural Equation Modelling (PLS-SEM). The structural path co-efficient $\left(\mathrm{R}^{2}\right)$ through PLS Algorithm Model, PLS Bootstrapping Model with $\beta$ and $p$-values and PLS Bootstrapping Model with $\beta$ and T-values is used to determines the level of significant influence of independent constructs on dependent. Meanwhile, the bootstrapping method which has been programmed by default in Smart PLS is 500 subsamples which, according to [81,82], helps to achieve significant results. The test of hypotheses helps to determine whether there is adequate statistical proof, or evidence in favour or against the formulated hypotheses. The convergent validity is determined from the indicators' item loadings; composite reliability and average variance are extracted. The item loadings of the reflective indicators exceed the minimum cut-off requirement of 0.60 .

\subsection{Results}

The hypothesis has two main variables i.e., organisational culture and environmental performance. In PLS-SEM, R-Square i.e., the coefficient of determination, structural path co-efficient ( $\beta$-value), T-statistic value, and the degree of goodness-of-fit model helps to determine the level of influence and relationship between the organisational culture and environmental performance as well as the model fitness. PLS Algorithm Model, PLS Bootstrapping Model with $\beta$ and $p$-values and PLS Bootstrapping Model with $\beta$ and T-values are presented in Figures 1-3 respectively. The algorithm helps to determine the path co-efficient and the significant values, while the bootstrapping helps in determining the significant testing of coefficient. The default bootstrapping in Smart PLS is 500 subsamples which helps to facilitate significant results. Therefore, the bootstrapping value was increased to 5000 as suggested by $[81,82]$ to enhance more specific and accurate results.

Figure 1 shows the PLS Algorithm Model of organisational culture and environmental performance. The path shows the resultant effect and level of relationship between exogenous variable and endogenous variable. In order to determine the level of variance of the endogenous variable, i.e., environmental performance, and exogenous variable, i.e., organisational culture, $R$ square $\left(R^{2}\right)$ values will be considered. $\mathrm{R}$ square is classified into substantial, moderate and weak. It can be regarded as substantial if the value is 0.75 ; it is classified as moderate if it is $\leq 0.50$. The $R$ square value that is $\leq 0.25$ 
is considered as weak, while $\leq 0.24$ is considered as not good. Figure 2 shows the $R^{2}=0.768$. This implies that $76.8 \%$ variation in environmental performance can be explained by organisational culture.

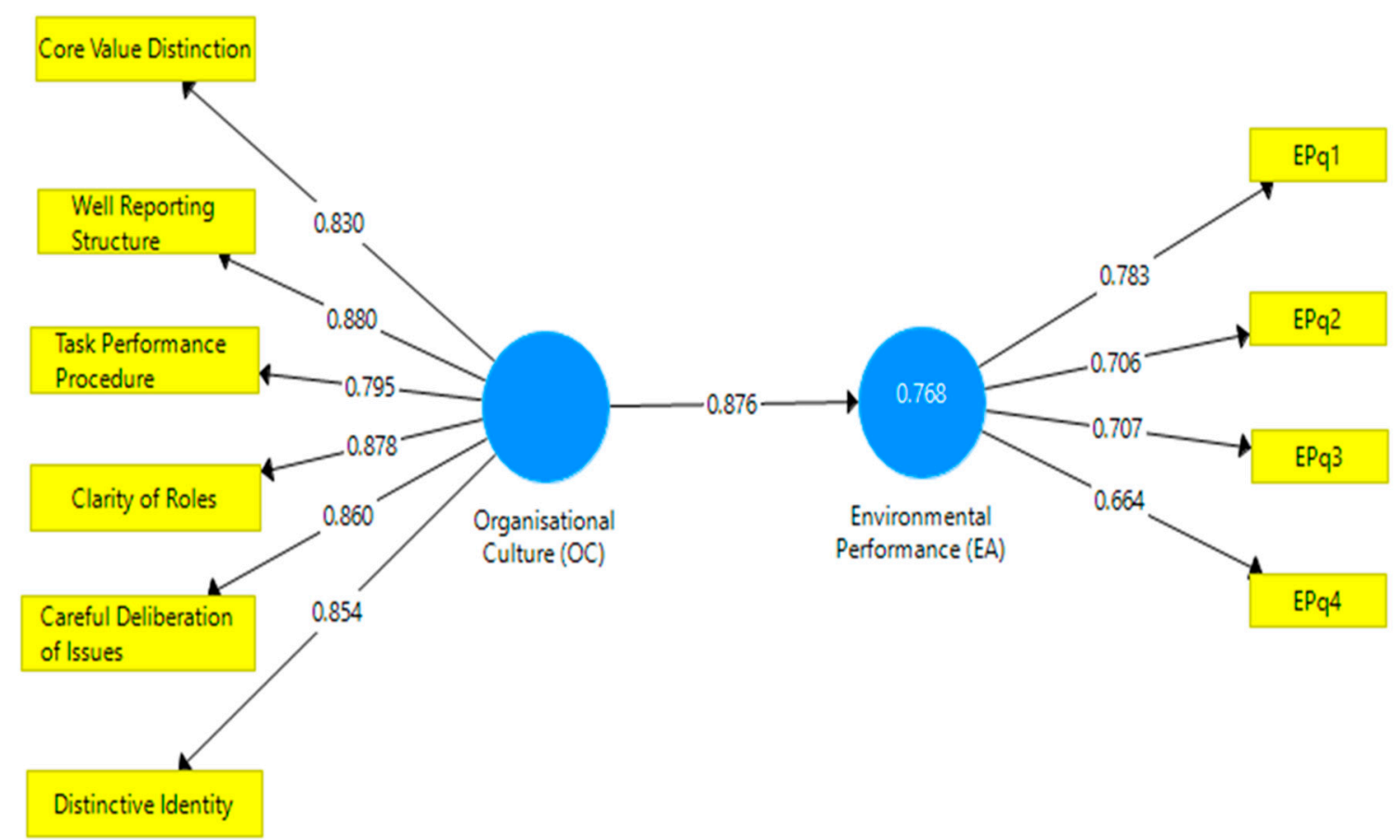

Figure 1. PLS Algorithm Model.

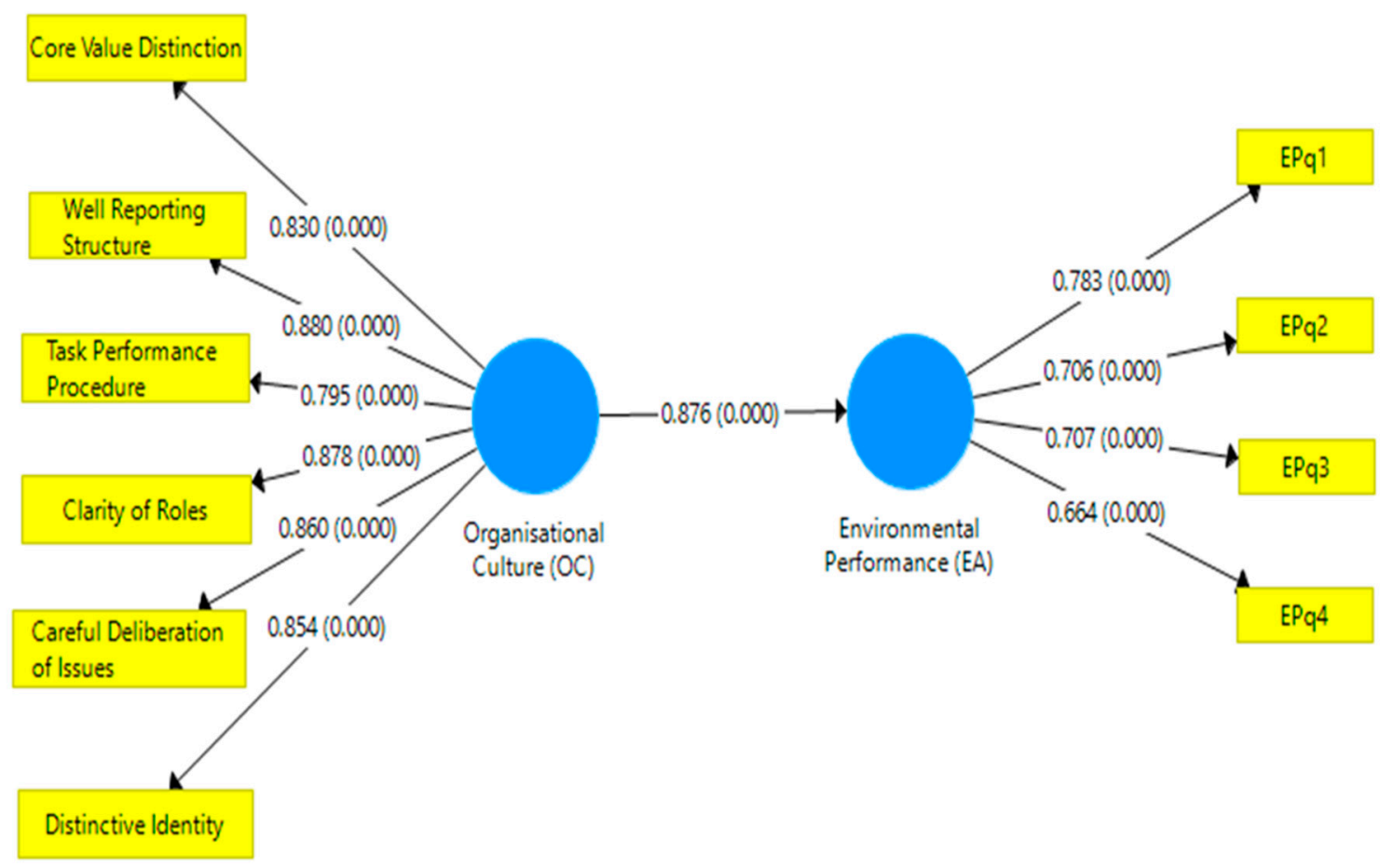

Figure 2. PLS Bootstrapping Model with $\beta$ and $p$-values. 


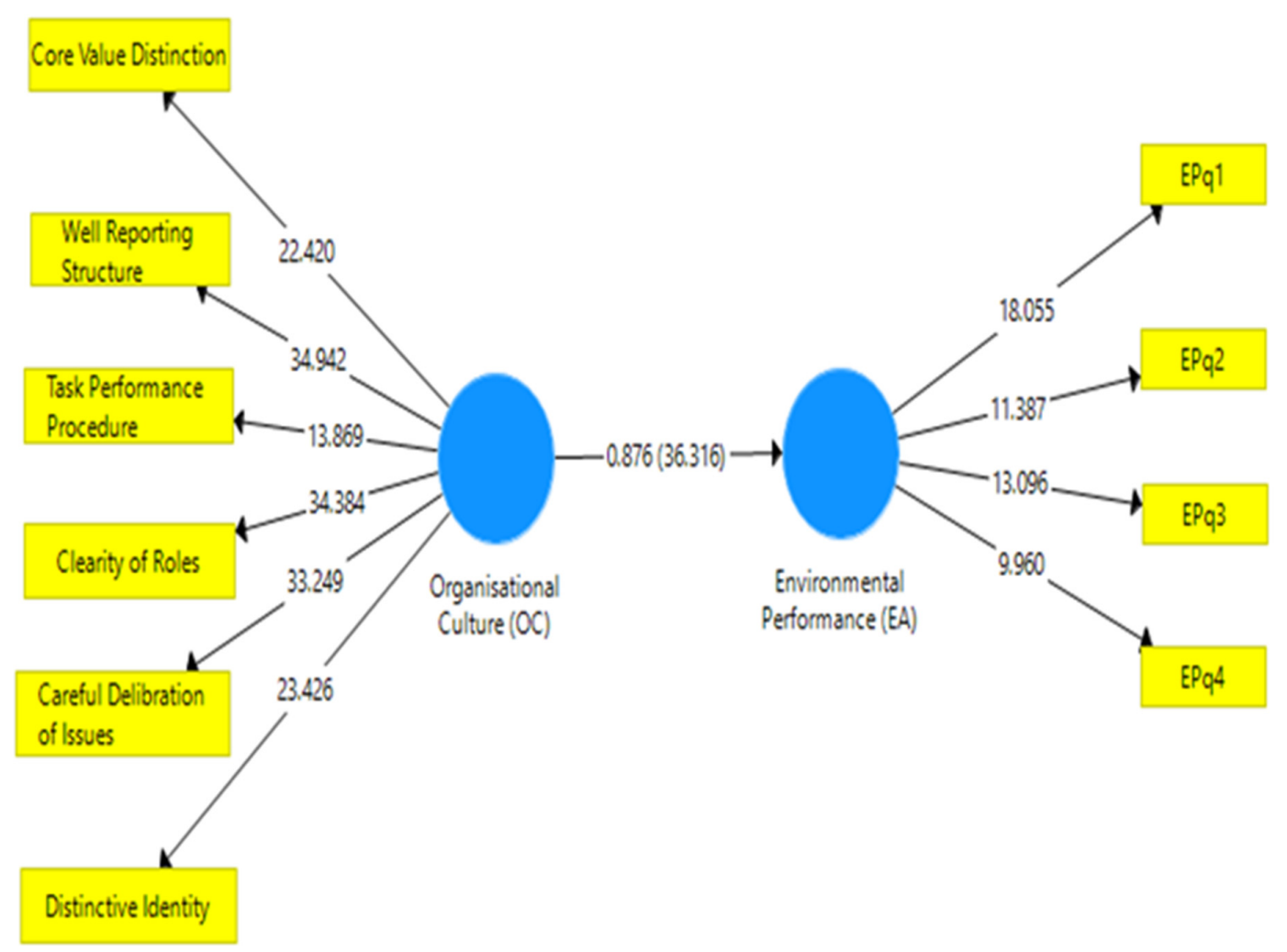

Figure 3. PLS Bootstrapping Model with $\beta$ and T-values.

The standard $\beta$ coefficient and smart PLS path coefficients are similar. The $\beta$-value indicates the expected variance in the dependent variable for a unit variation in the independent variable. This was used to test the significance of the hypothesis formulated. It is noteworthy that the greater the $\beta$-value, the more the substantial effect on environmental performance. The significant effect of organisational culture and environmental performance was verified through the T-statistical test. However, the path co-efficient is presented in Table 1.

Table 1. Path co-efficient.

\begin{tabular}{|c|c|c|c|c|c|}
\hline Variables & Loadings & T-Statistics & $p$-Values & Path Co-Efficient & $\mathbf{R}^{2}$ \\
\hline \multirow[t]{2}{*}{$\begin{array}{c}\text { Structural Path } \\
\text { Organisational Culture } \rightarrow \\
\text { Environmental Performance }\end{array}$} & & 36.316 & 0.000 & 0.876 & 0.768 \\
\hline & & & \multicolumn{3}{|c|}{ Importance-Performance Map } \\
\hline Measurement & & & & Performances & Importance \\
\hline Core Value Distinction & 0.830 & 22.420 & 0.000 & 54.273 & 0.178 \\
\hline Well Reporting Structure & 0.880 & 34.942 & 0.000 & 63.429 & 0.196 \\
\hline Task Performance Procedure & 0.795 & 13.869 & 0.000 & 56.667 & 0.136 \\
\hline Clarity of Roles & 0.878 & 34.384 & 0.000 & 63.000 & 0.193 \\
\hline Careful Deliberation of Issues & 0.860 & 33.249 & 0.000 & 59.963 & 0.165 \\
\hline Distinctive Identity & 0.854 & 23.426 & 0.000 & 56.406 & 0.159 \\
\hline EPq1 & 0.783 & 18.055 & 0.000 & & \\
\hline $\mathrm{EPq} 2$ & 0.706 & 11.389 & 0.000 & & \\
\hline EPq3 & 0.707 & 13.096 & 0.000 & & \\
\hline EPq4 & 0.664 & 9.960 & 0.000 & & \\
\hline \multirow{2}{*}{ Cronbach Alpha } & \multicolumn{3}{|c|}{ Organisational Culture } & & 0.923 \\
\hline & \multicolumn{3}{|c|}{ Environmental Performance } & & 0.783 \\
\hline \multirow{2}{*}{ Composite Reliability } & \multicolumn{3}{|c|}{ Organisational Culture } & & 0.940 \\
\hline & \multicolumn{3}{|c|}{ Environmental Performance } & & 0.808 \\
\hline \multirow{2}{*}{ AVE } & \multicolumn{3}{|c|}{ Organisational Culture } & & 0.722 \\
\hline & \multicolumn{3}{|c|}{ Environmental Performance } & & 0.613 \\
\hline
\end{tabular}


Table 1 and Figures 1-3 depict the PLS statistical results or outputs of the structural model. It was discovered that the structural path co-efficient of the six measures of organisational culture, i.e., core value distinction, well reporting structure, procedure for task performance, clearly defined roles, careful deliberation of issues and distinctive identity, indicate a significant relationship at 0.05 . In addition, the study revealed that core value distinction significantly influenced environmental performance at $($ T-value $=22.420>1.96, p$-value $=0.000<0.05)$.

\section{Discussions}

The study discovered that well reporting structure has significant influence on environmental performance at T-value $=34.942>1.94, p$-value $=0.000<0.05$, while task performance procedure also has significant influence on environmental performance at T-value $=13.869>1.96, p$-value $=0.000<0.05$. In a related development, it was also discovered that clarity of defined roles has significant influence on environmental performance at T-value $=34.384>1.96, p$-value $=0.000<0.05$, while careful deliberation of issues significantly influences environmental performance at T-value $=33.249>1.96$, $p$-value $=0.000<0.05$. Meanwhile, distinctive identity has significant influence on environmental performance at T-value $=23.426>1.96, p$-value $=0.000<0.05$.

In a nutshell, the path co-efficient shows that the level of influence of organisational culture on environmental performance is statistically significant with beta value of $0.876, R^{2}$ of 0.768 with T-statistical value of 36.316 and $p$-value of 0.000 . This implies that organisational culture has significant influence on environmental performance. Generally, the $\mathrm{R}^{2}$ of 0.768 suggests $76.8 \%$ influence on the principal variable, i.e., if one unit of organisational culture increases, then $76.8 \%$ environmental performance will increase.

In terms of importance, well reporting structure is the most important variable among the six items at a value of 0.300 , followed by clarity of roles at a value of 0.193 , while core value distinction was at a value of 0.178 ; also, deliberation of issues at the value of 0.165 , then distinctive identity at 0.159 and finally, task performance procedure at 0.136 has the least importance with a score of 0.05 . This implies that it is only logical to invest more in the dimension of an organisation's cultural variables that have high performance-importance, while adequate attention should be given to variables that have least influence on the target construct of environmental performance.

Table 2 depicts various forms of goodness-of-fit indicators' threshold in assessing the specified model of the study. The goodness-of-fit indices presented in the table according to $[83,84]$ are as recommended, and within the benchmark range of acceptance. The SRMR value is 0.027 which is less than the acceptable benchmark value of 0.08 ; and NFI value is 0.744 within $0+1$, suggesting a good fit of the model. Additionally, chi-square per degree of freedom ratio $\left(x^{2} / \mathrm{df}\right)$ and other indicators presented in the table are within the threshold.

Table 2. Model goodness-of-fit statistics.

\begin{tabular}{ccc}
\hline Model Fit Indicators & Benchmark & Saturated Model \\
\hline SRMR & $<0.08$ & 0.027 \\
CMIN/DF & $<3$ & 1.264 \\
d-G (Geodesic Distance) & $>0.08$ & 2.777 \\
Chi Square & $>0.05$ & 817.741 \\
NFI & Between $0+1$ & 0.744 \\
\hline
\end{tabular}

\section{Conclusions and Implications}

Our findings show that most respondents agreed to have core values as a positive predisposition towards the production of ecological-friendly goods. As a result, it differentiates them from that of their competitors. This finding implies that organisations contribute significantly to the performance of the environment. Organisational culture in this context is common values shared by members of an organisation for a purpose, cause, or goal, to which the organisation is known for, and identified by it. 
Another finding from the sample survey is that most organisations primarily conveyed their core-value messages and sensitized their employees with their environmental values. It resulted in members being aware of the shared-value of the organisation. There is a relative finding with Baird et al. [9] work that indicates three of the dimensions of its organisational culture exhibit association with a specific aspect of the environmental activity management (EAM). Similarly, the result of Magsi et al. [2] revealed that organisational culture is a latent variable that substantially impacts environmental performance. As a study conducted in Pakistan with different cultural contexts, it deemed fit to replicate the study in Nigeria and, thus, correlates with the findings.

Several studies also reported similar findings. Pham et al. [36] revealed organisational culture playing a moderating role of green practices of organisational citizenship behaviour toward the environment. More studies Akhavan et al. [37] and Aktas et al. [39] are also consistent with the finding which shows knowledge management plays a prominent role in creating environmental responsiveness as a culture. This is to enable the organisation having a competitive edge in the competitive business environment. The implication is a positive collaboration of both internal and external environments, and it serves as a value to the management.

This study is based on clear evidence that organisational culture has a strong pivot of influence in directing the workforce's behavioural tendencies. This, in conclusion, is significantly related to its impact on environmental performance. It indicates that their activities as a norm, impact the environment principally through the efficient use of water and energy, as well as the production of waste emissions and having a culture of responsible consumption and production.

The managers of the FMCGs are to embrace a holistic culture that proffers for more environmentally-friendly policies, that cares for both the society and the ecosystem in terms of well reporting structure and distinctive core value. Moreover, in the area of task performance, the procedure should be well explicit to all the stakeholders.

\section{Limitations and Future Study}

It is imperative to note here that in the course of carrying out this study, the researchers encountered some limitations. The study was limited in scope as it only covered four Fast-Moving Consumer Goods (FMCGs) firms in southwestern Nigeria, and as such, the result may not have been generalised to other FMCGs firms. Although, other FMCGs will find the findings of this study relevant because they tend to have similar characteristics, and the southwest region of the country is highly representative of other parts of the country in this regard. This is because the southwest of Nigeria is the commercial nerve of the country. However, future studies could cover the other geo-political zones in Nigeria.

The sample size for this study was also determined by using the formula recommended by Guilford, \& Fruchter [80], however, using an alternative method for the sample size determination in other studies may offer a different sample size.

This study only focused on FMCGs; meanwhile, for a generalised perspective, a comparative study could be carried out in other manufacturing sectors to compare and validate the applicability of the findings in Nigeria.

Author Contributions: All authors contributed equally to this work. O.P.A. and R.E.W. collected and drafted the paper; O.P.A. and O.O.O. analyzed the data; O.P.A. and C.L.M. reviewed related studies. All authors wrote, reviewed and commented on the manuscript. All authors have read and approved the final manuscript.

Funding: The Article Processing Charges (APC) was funded by Covenant University Centre for Research, Innovation and Discovery (CUCRID).

Conflicts of Interest: The authors declare no conflict of interest. 


\section{References}

1. Reyes-Santiago, M.R.; Sánchez-Medina, P.S.; Díaz-Pichardo, R. Eco-innovation and organizational culture in the hotel industry. Int. J. Hosp. Manag. 2017, 65, 71-80.

2. Magsi, H.B.; Ong, T.S.; Ho, J.A.; Hassan, A.F.S. Organizational culture and environmental performance. Sustainability 2018, 10, 2690. [CrossRef]

3. Srisathan, W.A.; Ketkaew, C.; Naruetharadhol, P. The intervention of organizational sustainability in the effect of organizational culture on open innovation performance: A case of Thai and Chinese SMEs. Cogent Bus. Manag. 2020, 7, 1717408. [CrossRef]

4. Gochhayat, J.; Giri, V.N.; Suar, D. Influence of organizational culture on organizational effectiveness: The mediating role of organizational communication. Glob. Bus. Rev. 2017, 18, 691-702. [CrossRef]

5. Wheelen, T.L.; Hunger, J.D. Strategic Management and Business Policy: Toward Global Sustainability, 13th ed.; Pearson Education, Inc.: New York, NY, USA, 2012.

6. Liao, Z. Corporate culture, environmental innovation and financial performance. Bus. Strategy Environ. 2018, 27, 1368-1375. [CrossRef]

7. Felipe, C.M.; Roldán, J.L.; Leal-Rodríguez, A.L. Impact of Organizational Culture Values on Organizational Agility. Sustainability 2017, 9, 2354. [CrossRef]

8. Linnenluecke, M.K.; Griffiths, A. Corporate sustainability and organizational culture. J. World Bus. 2010, 45, 357-366. [CrossRef]

9. Baird, K.; Su, S.; Tung, A. Organizational Culture and Environmental Activity Management. Bus. Strategy Environ. 2018, 27, 403-414. [CrossRef]

10. Küçükoğlu, M.T.; Pınar, R.I. The mediating role of green organizational culture between sustainability and green innovation: A research in Turkish companies. Bus. Manag. Stud. Int. J. 2018, 6, 64-85. [CrossRef]

11. Kucukoglu, M.T.; Pinar, R.I. Positive influences of green innovation on company performance. Procedia Soc. Behav. Sci. 2015, 195, 1232-1237. [CrossRef]

12. Xing, X.; Wang, J.; Tou, N. The relationship between green organization identity and corporate environmental performance: The mediating role of sustainability exploration and exploitation innovation. Int. J. Environ. Res. Public Health 2019, 16, 921. [CrossRef] [PubMed]

13. Ugwa, M.; Okonkwo, C.J. The impact of organizational environment on corporate performance. Res. J. Commer. Behav. Sci. 2014, 3, 36-45.

14. Henri, J.F.; Journeault, M. Environmental performance indicators: An empirical study of Canadian manufacturing firms. J. Environ. Manag. 2008, 87, 165-176. [CrossRef] [PubMed]

15. Babalola, Y.A. The impact of corporate social responsibility on firms' profitability in Nigeria. Eur. J. Econ. Financ. Adm. Sci. 2012, 45, 39-50.

16. Iljins, J.; Skvarciany, V.; Gaile-Sarkane, E. Impact of organizational culture on organisational climate during the process of change. Procedia Soc. Behav. Sci. 2015, 213, 944-950. [CrossRef]

17. Odor, H.O. Organisational Culture and Dynamics. Int. J. Sci. Res. Manag. 2018, 6, 31-39.

18. Onyango, W.P. Effects of organization culture on change management: A case of the vocational training centre for the blind and deaf, Sikri. Eur. J. Bus. Manag. 2014, 6, 204-214.

19. Hategan, C.D.; Sirghi, N.; Curea-Pitorac, R.I.; Hategan, V.P. Doing well or doing good: The relationship between corporate social responsibility and profit in Romanian companies. Sustainability 2018, 10, 1041. [CrossRef]

20. Kangas, M.; Kaptein, M.; Huhtala, M.; Lamsa, A.M.; Pihlajasaari, P.; Feldt, T. Why do managers leave their organisation? Investigating the role of ethical organisational culture in managerial turnover. J. Bus. Ethic 2018, 153, 707-723. [CrossRef]

21. Chiou, T.-Y.; Chan, H.K.; Lettice, F.; Chung, S.H. The influence of greening the suppliers and green innovation on environmental performance and competitive advantage in Taiwan Transport. Res. E Logist. Transp. Rev. 2011, 47, 822-836. [CrossRef]

22. Rooij, B.; Fine, A. Toxic corporate culture: Assessing organizational processes of deviancy. Adm. Sci. 2018, 8, 23. [CrossRef]

23. Tahir, R.; Athar, M.R.; Faisal, F.; Shahani, N.N.; Solang, B. Green Organizational Culture: A Review of Literature and Future Research Agenda. Ann. Contemp. Dev. Manag. HR 2019, 1, 23-38. [CrossRef] 
24. Moses, C.L.; Olokodun, M.A.; Akinbode, M.; Agboola, M.G. Organisational culture and creativity in entrepreneurship education: A study of secondary education in Nigeria. Res. J. Appl. Sci. 2016, 11, 586-591.

25. Ibidunni, S.; Agboola, M.G. Organizational Culture: Creating, Changing, Measuring and Consolidating for Performance. Eur. J. Bus. Manag. 2013, 5, 177-186.

26. Johnson, G.; Scholes, K.; Whittington, R. Exploring Corporate Strategy, 7th ed.; Pearson Education Ltd.: London, UK, 2005.

27. Schein, E.H. Organizational culture. Am. Psychol. 1990, 45, 111. [CrossRef]

28. Trompenaars, F.; Turner, C.H. Riding the Waves of Culture, 3rd ed.; McGraw Hill: New York, NY, USA, 2012.

29. Hofstede, G.; Hofstede, G.J.; Minkov, M. Cultures and Organisations: Software of the Mind. Intercultural Cooperation and Its Importance for Survival; McGraw-Hill Publishers: New York, NY, USA, 2010.

30. Robbins, S.P.; Judge, T.A. Organisational Behaviour (What's New in Management), 18th ed.; Pearson Education, Inc. Prentice Hall: Upper Saddle River, NJ, USA, 2018.

31. Daft, R.L. Management, 12th ed.; South-Western Cengage Learning Publishers Inc.: Mason, OH, USA, 2017.

32. Falope, F.J.; Offor, N.T.; Ofurum, D.I. Environmental cost disclosure and corporate performance of quoted construction firms in Nigeria. Int. J. Adv. Acad. Res. 2019, 5, 17-31.

33. Orji, F.M. Management of Environmental Issues in the Nigerian Oil-Producing Region: A Framework for Stakeholders' Collaboration. Ph.D. Thesis, University of Central Lancashire, Preston, UK, 2018.

34. Latan, H.; Jabbour, C.J.C.; Jabbour, A.B.L.; Wamba, S.F.; Shahbaz, M. Effects of environmental strategy, environmental uncertainty and top management's commitment on corporate environmental performance: The role of environmental management accounting. J. Clean. Prod. 2018, 180, 297-306. [CrossRef]

35. Chin, T.A.; Tat, H.H.; Sulaiman, Z. Green supply chain management, environmental collaboration and sustainability performance. Procedia CIRP 2015, 26, 695-699. [CrossRef]

36. Pham, N.T.; Phan, Q.P.T.; Tučková, Z.; Vo, N.; Nguyen, L.H.L. Enhancing the organizational citizenship behavior for the environment: The roles of green training and organizational culture. Manag. Mark. Chall. Knowl. Soc. 2018, 13, 1174-1189. [CrossRef]

37. Akhavan, P.; Sanjaghi, M.B.; Rezaeenour, J.; Ojaghi, H. Examining the relationships between organizational culture, knowledge management and environmental responsiveness capability. J. Inf. Knowl. Manag. Syst. 2014, 44, 228-248.

38. Gu, V.C.; Hoffman, J.J.; Cao, Q.; Schniederjans, M.J. The effects of organisational culture and environmental pressures on IT project performance: A moderation perspective. Int. J. Proj. Manag. 2014, 32, 1170-1181. [CrossRef]

39. Aktas, E.; Çiçek, I.; Kıyak, M. The effect of organisational culture on organisational efficiency: The moderating role of organisational environment and CEO values. Procedia Soc. Behav. Sci. 2011, 24, 1560-1573. [CrossRef]

40. Alhadid, A.; Abu-Rumman, H. The impact of green innovation on organizational performance, environmental management behavior as a moderate variable: An analytical study on Nuqul Group in Jordan. Int. J. Bus. Manag. 2014, 9, 51-58. [CrossRef]

41. Porter, T.H.; Gallagher, V.C.; Lawong, D. The greening of organizational culture: Revisited fifteen years later. Am. J. Bus. 2016, 31, 206-226. [CrossRef]

42. Fok, L.Y.; Zee, S.M.L.; Hartman, S.J. Relationships among individual green orientation, employee perceptions of organisational commitment to the green movement, and organisational culture: A comparative study of Jamaica and the United States. J. Organ. Cult. Commun. Conf. 2012, 16, 125-134.

43. Jabbour, C.J.C. How green are HRM practices, organizational culture, learning and teamwork? A Brazilian study. Ind. Commer. Train. 2011, 43, 98-105. [CrossRef]

44. Afum, E.; Agyabeng-Mensah, Y.; Owusu, J.A. Translating environmental management practices into improved environmental performance via green organizational culture: Insight from Ghanaian manufacturing SMEs. J. Supply Chain Manag. Syst. 2020, 9, 31-49.

45. Gyasi-Mensah, W.; Xuhua, H. Towards developing a green manufacturing environment: What is Ghana doing? Environ. Manag. Sustain. Dev. 2018, 7, 170-180. [CrossRef]

46. Efobi, U.; Belmondo, T.; Orkoh, E.; Atata, N.S.; Akinyemi, O.; Beecroft, I. Environmental pollution policy of small businesses in Nigeria and Ghana: Extent and impact. Environ. Sci. Pollut. Res. 2019, 26, 2882-2897. [CrossRef]

47. Fatoki, O. Green marketing orientation and environmental and social performance of hospitality firms in South Africa. Found. Manag. 2019, 11, 277-290. [CrossRef] 
48. Fatoki, O. Organisational culture and environmental performance of hospitality firms in South Africa. J. Environ. Manag. Tour. 2019, 10, 575-589. [CrossRef]

49. Motilewa, B.D.; Agboola, G.M.; Adeniji, C.M. Organisational culture and performance. In Covenant University. International Conference on African Development Issues (CU-ICADI), 2nd ed.; Africa Leadership Development Center, Covenant University: Ota, Nigeria, 2015; pp. 297-300.

50. Piwowar-Sulej, K. Pro-Environmental organizational culture: Its essence and a concept for its operationalization. Sustainability 2020, 12, 4197. [CrossRef]

51. Taylor, G.D.; Van Aken, E.M.; Smith-Jackson, T. Improving Organizational Culture Using Core Values 19th International Conference on Production Research; Pontifical Catholic University of Valparaiso: Valparaiso, Chile, 2007.

52. Renwick, D.W.S.; Jabbour, C.J.C.; Muller-Camen, M.; Redman, T.; Wilkinson, A. Contemporary developments in Green (environmental) HRM scholarship. Int. J. Hum. Resour. Manag. 2016, 27, 114-128. [CrossRef]

53. Kumar, A. Redefined and Importance of Organizational Culture. Glob. J. Mamag. Bus. Res. 2016, 16, 15-18.

54. Delic, A.; Nuhanovic, S. The organizational structure and organizational culture interdependence analysis with special reference to Bosnian and Herzegovinian enterprise. Organ. Econ. Ann. 2010, 43, 70-80.

55. Ahmadya, G.A.; Mehrpourb, M.; Nikooravesh, A. Organizational Structure. Procedia Soc. Behav. Sci. 2016, 230, 455-462. [CrossRef]

56. Peprah, W.K.; Ganu, J. The Convergence of Organizational Culture, Structure and Human Capital Performance: A Conceptual Analysis. Arch. Bus. Res. 2018, 6, 212-221. [CrossRef]

57. Perawironegoro, D. The Relationship between Organizational Structure and Organizational Culture with Teacher Performance in Pesantren. Adv. Soc. Sci. Educ. Hum. Res. 2018, 200, 710-716.

58. Janićijević, N. The mutual impact of organizational culture and structure. Econ. Ann. 2013, 58, 35-60. [CrossRef]

59. Oshita, M.G.B.; Pavao, J.A.; Borges, I.M.T. Analysis of the organization structure of enterprises of technological basis with project without incubators. Int. J. Innov. 2017, 5, 211-221. [CrossRef]

60. Owoyemi, O.O.; Ekwoaba, J.O. Organisational culture: A tool for management to control, motivate and enhance employee's performance. Am. J. Bus. Manag. 2014, 3, 168-177. [CrossRef]

61. Kalia, N.; Bhardwaj, B. Contextual and task performance: Do demographic and organizational variables matter? Rajagiri Manag. J. 2019, 13, 30-42. [CrossRef]

62. Daryoush, Y.; Silong, A.D.; Omar, Z.; Othman, J. Improving job performance: Workplace learning is the first step. Int. J. Educ. Lit. Stud. 2013, 1, 100-107. [CrossRef]

63. Daderman, A.M.; Ingelgard, A.; Koopman, L. Cross-cultural adaptation, from Dutch to Swedish language, of the Individual Work Performance Questionnaire. Work 2020, 65, 97-109. [CrossRef] [PubMed]

64. Kappagoda, S. Self-efficacy, task performance and contextual performance: A Sri Lankan experience. J. Hum. Res. Sustain. Stud. 2018, 6, 161-170.

65. Ramos-Villagrasa, P.J.; Barrada, J.R.; Fernández-del-Río, E.; Koopmans, L. Assessing job performance using brief self-report scales: The case of the individual work performance questionnaire. J. Work. Org Psychol. 2019, 35, 195-205. [CrossRef]

66. Lynn, G.S.; Kalay, F. The effect of vision and role clarity on team performance. Int. J. Econ. Adm. Stud. 2016, 17, 175-196. [CrossRef]

67. Samie, F.; Riahi, L.; Tabibi, S.J. The relationship between role clarity and efficiency of employees in management \& resource development department of ministry of health and medical education of Iran. Biosci. Biotechnol. Res. Asia 2015, 12, 2803-2812.

68. Mumley, W.E. Organizational culture and ethical decision-making during major crises. J. Values Based Leadersh. 2019, 12, 9-17. [CrossRef]

69. Hassan, S. The importance of role clarification in workgroups: Effects on perceived role clarity, work satisfaction, and turnover rates. Public Adm. Rev. 2013, 73, 716-725. [CrossRef]

70. Marchisotti, G.G.; Almeida, R.L.; Domingos, M.L.C. Decision-making at the first management level: The interference of the organizational culture. Rev. Adm. Mackenzie 2018, 19, 1-26. [CrossRef]

71. Naz, S.; Ilyas, M.I.; Rehman, C.A. Impact of organizational culture on decision making style: Empirical findings of textile industry in Pakistan. Sci. Int. 2015, 27, 431-438.

72. Gould, R.K.; Krymkowski, D.H.; Ardoin, N.M. The importance of culture in predicting environmental behavior in middle school students on Hawai 'i Island. PLoS ONE 2018, 13, e0207087. [CrossRef] [PubMed] 
73. Jalal, A. Impacts of organizational culture on leadership's decision making. J. Adv. Manag. Sci. Inf. Syst. 2017, 3, 1-8. [CrossRef]

74. Azadehdel, M.R.; Ooshaksaraie, M.; Rajabpour, S. The importance of organizational identity and its role in the performance. Kuwait Chapter Arab. J. Bus. Manag. Rev. 2013, 3, 67-74. [CrossRef]

75. Taha, V.A.; Sirkova, M.; Ferencova, M. The impact of organizational culture on creativity and innovation. Pol. J. Manag. Stud. 2016, 14, 7-17. [CrossRef]

76. Adebayo, O.P.; Kehinde, O.J.; Ogunnaike, O.O.; Olaoye, O.P.; Adesanya, O.D. Corporate brand identity and service quality in higher education management. Pol. J. Manag. Stud. 2019, 20, 45-59.

77. Mujib, H. Organizational identity: An ambiguous concept in practical terms. Adm. Sci. 2017, 7, 28. [CrossRef]

78. Farayola, S.O.; Adeleke, B.S. Does product innovation strategy bolster competitive edge in the Nigerian Fast-Moving-Consumable-Goods (FMCG) industry? Int. J. Bus. Entrep. Res. 2018, 11, 104-114.

79. Medase, K.; Barasa, L. Absorptive capacity, marketing capabilities, and innovation commercialisation in Nigeria. Eur. J. Innov. Manag. 2019, 22, 790-820. [CrossRef]

80. Guilford, J.P.; Fruchter, B. Fundamental Statistics in Psychology and Education, 5th ed.; McGraw Hill: New York, NY, USA, 1973.

81. Ringle, C.M.; Sarstedt, M.; Mitchell, R.; Gudergan, S.P. Partial least squares structural equation modeling in HRM research. Int. J. Hum. Resour. Manag. 2020, 31, 1617-1643. [CrossRef]

82. Sarstedt, M.; Ringle, C.M.; Hair, J.F. Partial least squares structural equation modeling. In Handbook of Market Research; Homburg, C., Klarmann, M., Vomberg, A., Eds.; Springer: Berlin/Heidelberg, Germany, 2017.

83. Aguirre-Urreta, M.I.; Rönkkö, M. Statistical inference with PLS using bootstrap confidence intervals. MIS Q. 2018, 42, 1001-1020. [CrossRef]

84. Hair, J.F.; Sarstedt, M.; Ringle, C.M. Rethinking some of the rethinking of partial least squares. Eur. J. Mark. 2019, 53, 566-584. [CrossRef]

(C) 2020 by the authors. Licensee MDPI, Basel, Switzerland. This article is an open access article distributed under the terms and conditions of the Creative Commons Attribution (CC BY) license (http://creativecommons.org/licenses/by/4.0/). 